Faruk H. AVDIĆ, MA*

Independent researcher Tuzla, Bosnia \& Herzegovina
Review paper

Received: 11 November 2021

Accepted: 30 November 2021

UDK: 341.231.14

340.142:341.645(4)

https://doi.org/10.47152/rkkp.59.3.5

\title{
THE EROSION OF THE SALDUZ DOCTRINE IN THE CASES OF IBRAHIM AND OTHERS $V$. THE UNITED KINGDOM AND BEUZE V. BELGIUM
}

The so-called Salduz doctrine that concerns the right to a fair trial and the right to the defense attorney emerged from the case of Salduz v. Turkey, decided on the part of the European Court of Human Rights where the Grand Chamber found the violation of Article 6, paragraph 3(c) of the Convention for the Protection of Human Rights and Fundamental Freedoms. In this connection, the aim of this paper is twofold. In the first place, the paper aims to demonstrate how the European Court of Human Rights has overturned the two main tenents of the so-called Salduz doctrine derived from its landmark case of Salduz v. Turkey in its later Judgments delivered in the case of Ibrahim and Others v. the United Kingdom and the case of Beuze v. Belgium. The two tenets derived from the Salduz doctrine being examined in the paper are the right to access to the defense attorney as a rule during pre-trial proceedings and the absolute exclusionary rule. In the second place, the paper aims to offer a critique of the standard of compelling reasons employed in the Ibrahim Judgment. In order to achieve its aim, this paper primarily analyses the jurisprudence of the European Human Court of Human Rights in the cases of Salduz v. Turkey, Ibrahim and Others v. the United Kingdom, and Beuze v. Belgium. Besides, the paper

\footnotetext{
*E-mail: hadziavdicfaruk@gmail.com, ORCID: https://orcid.org/0000-0001-7567-5588.
} 
also touches upon other judgments of the European Court of Human Rights related to its subject. The paper in question, therefore, primarily relies on the case-law method in achieving its aims. The paper concludes that in overturning the Salduz doctrine in relation to aspects examined in the paper, the European Court of Human Rights has exacerbated the legal standing of the person against whom criminal proceedings are being conducted.

Keywords: Salduz doctrine, Salduz case, restriction of the right to access the defense attorney, the absolute exclusionary rule, Ibrahim case, Beuze case.

\section{Introduction}

According to the provisions of the Convention for the Protection of Human Rights and Fundamental Freedoms (hereinafter: the ECHR), among other things, everyone charged with a criminal offense has the right to defend himself in person or through legal assistance of his own choosing or, if he has not sufficient means to pay for legal assistance, to be given it free when the interests of justice so require (Article 6, paragraph 3(c) of the ECHR). In this connection, it is worth observing that the provision of Article 6, paragraph 3(c) differentiates between the substantive and the formal aspects of the right to defense. While the right to defense understood in the substantive sense supposes the right of the defendant to undertake in his favor any procedural actions standing at his disposal, such as examining witnesses and expert witnesses, proposing exculpating evidence, challenging incriminating evidence, the right to defense in the formal sense means the right to have the professional assistance and services of the defense attorney, which is in practice the main thrust of Article 6, paragraph 3(c) of the ECHR (Trechsel, 2005: 244). The right to the defense attorney is one of the fundamental features of a fair trial and consequently of the rule of law (Soo, 2018: 19). As other rights included in the ECHR, especially those being elements of a right to a fair trial, for proper understanding of the right to the defense attorney, one needs to take a closer look at the jurisprudence of the ECtHR. When it comes to the right to defense attorney under the ECHR and the jurisprudence of the ECtHR, two issues bearing significant theoretical and practical implications attract a great deal of attention, whereby the latter is far more controversial. The first question that ought to be answered is when the right to the defense attorney arises in the course of criminal proceedings. In other words, in which stage of the criminal proceedings the defendant must be provided with the right to the legal assistance and 
services of the defense attorney. The second question deserving answering is whether high contracting parties enjoy the right to subject the right to the defense attorney to certain restrictions and which consequences occur if such restrictions arise during criminal proceedings. Regarding the first posed question as to whether Article 6 of the ECtHR covers the right of access to the defense attorney only at the stage of the court proceedings or whether this right also applies during the pre-trial stage of criminal proceedings, it could be said that the right to access to the defense attorney is observed by the ECtHR in light of the right to a fair trial. Moreover, the ECtHR has clarified on numerous occasions that the right laid out in Article 6, paragraph 3(c) of the ECHR is one element, amongst others, of the concept of a fair trial in criminal proceedings contained in Article 6, paragraph 1 of the ECHR (ECtHR, Artico v. Italy, no. 6694/74, paras. 32-33, Judgment of 13 May 1980, Series A no. 37; ECtHR, Quaranta v. Switzerland, no. 12744/87, para. 27, Judgment of 24 May 1991, Series A no. 205). In the case of Imbrioscia v. Switzerland, the ECtHR said that other requirements derived from Article 6 of the ECtHR, especially those of Article 6, paragraph 3 of the ECHR, ,may also be relevant before a case is sent for trial if and in so far as the fairness of the trial is likely to be seriously prejudiced by an initial failure to comply with them" (ECtHR, Imbrioscia v. Switzerland, no. 13972/88, para. 36, Judgment of 24 November 1993, Series A no. 275). Even though the ECtHR made it clear that everyone charged with a criminal offense has the right to defend himself in person or through legal assistance pursuant to Article 6, paragraph 3(c) of the ECHR, the ECtHR at the same time opined that the cited provision does not specify the manner of exercising this right (Imbrioscia v. Switzerland, para. 38). It thus leaves to the Contracting States the choice of the means of ensuring that it is secured in their judicial systems, the ECtHR's task being only to ascertain whether the method they have chosen is consistent with the requirements of a fair trial (Quaranta v. Switzerland, para. 30; Imbrioscia $v$. Switzerland, para. 38). In this connection, the ECtHR stressed that the ECHR is aimed at guaranteeing not rights that are theoretical or illusory but rights that are practical and effective and that assigning the defense attorney does not in itself ensure the effectiveness of the assistance he may afford an accused (Artico v. Italy, para. 33; Imbrioscia v. Switzerland, para. 38).

When it comes to the right to the defense attorney under the ECHR or, to be more specific, the restrictions of this right and their ramifications for criminal proceedings taken as a whole, one can differentiate between the pre-Salduz era, the Salduz era, and the post-Salduz era. The standard the ECtHR applied before the Salduz doctrine regarding restricting the access to legal advice during pretrial proceedings was a more lenient one. This approach was exemplified in the case of John Murray v. the United Kingdom decided on the part of the Grand 
Chamber, as well as in the case of Brennan v. the United Kingdom, when the ECtHR recognized that national laws may attach consequences to the attitude of an accused at the initial stages of police interrogation, which are decisive for the prospects of the defense in any subsequent criminal proceedings. The ECtHR went on further to say that even though in such circumstances guarantees derived from Article 6 of ECHR will normally require that the accused be allowed to benefit from the assistance of the defense attorney already at the initial stages of police interrogation, this right, which is not explicitly laid out in the ECHR, may be subject to restrictions for good cause. In this connection, the question arising in each case is whether the restriction has deprived the accused of a fair hearing in light of the entirety of the proceedings (ECtHR, John Murray v. the United Kingdom, no. 18731/91, para. 63, Judgment of 8 February 1996 [GC], Reports of Judgments and Decisions 1996-I; ECtHR, Brennan v. the United Kingdom, no. 39846/98, para. 45, Judgment of 16 October 2001, ECHR 2001-X). Therefore, one can make two conclusions with regard to the stance of the ECtHR when it comes to the deprivation of the right to the defense attorney during the initial stages of criminal proceedings before the emergence of the Salduz doctrine. In the first place, the jurisprudence of the ECtHR failed to provide any precise guidance on how to understand the concept of "good cause" (Sakowicz, 2021: 1986). In the second place, by taking a stance that restrictions of the right of access to the defense attorney should be assessed through the lenses of compliance with the requirement of a fair trial as a whole, the ECtHR significantly weakened the essence of this right (Sakowicz, 2021: ibid.).

\section{Salduz v. Turkey}

\subsection{The Circumstances of the Case}

The applicant Yusuf Salduz, a minor at the time of the conduction of the criminal proceedings against him, was charged on suspicion of having participated in an unlawful demonstration in support of an illegal organization. Besides, the applicant was also accused of hanging an illegal banner from a bridge in a local town in the Republic of Turkey (ECtHR, Salduz v. Turkey, no. 36391/02, paras. 4-5, Judgment of 26 April 2007). At the beginning of the criminal proceedings, the police officers took a statement from the applicant in which he admitted the charges (Salduz v. Turkey, para. 6). Afterward, the applicant was brought before the public prosecutor and then the investigating judge. In front of both of these officials, the applicant denied the content of his police statement, alleging that it had been extracted from him under duress. The same day, the applicant was 
remanded in custody (Salduz v. Turkey, para. 7). The Izmir State Security Court convicted the applicant of aiding and abetting the terrorist organization (Salduz v. Turkey, paras. 8-9). As a basis for convicting the applicant, the Izmir State Security Court had taken into consideration the statements which the applicant had made to the police, the public prosecutor, and the investigating judge, as well as his co-defendants' testimony before the public prosecutor and other evidence (Salduz v. Turkey, para. 10). In the end, the Judgment of the Izmir State Security Court was confirmed by the Court of Cassation (Salduz v. Turkey, para. 12).

\subsection{The Judgment of the Chamber}

The case of Salduz v. Turkey (hereinafter also: the Salduz case) was first decided by the Chamber of the European Court of Human Rights (hereinafter: the Chamber) before the Grand Chamber of the European Court of Human Rights (hereinafter: the Grand Chamber) delivered its Judgment (hereinafter also: the Salduz Judgment) in the same case giving rise to the so-called Salduz doctrine. When examining the complaints of the applicant, the Chamber observed that the applicant was represented at the trial held before the Izmir State Security Court and during the appeals proceedings by his lawyer. Moreover, the Chamber stressed that statement the applicant made to the police during his pre-trial detention was not the sole basis for his conviction, and that he had had the opportunity of challenging the prosecution's allegations under conditions that did not place him at a substantial disadvantage vis-à-vis his opponent. According to the view of the Chamber, the court convicted the applicant on the basis of the facts and evidence before it as a whole (Salduz v. Turkey, para. 23). Having considered the above circumstances of the case in question, the Chamber held that the fairness of the applicant's trial was not prejudiced in this particular case in view of the fact that the applicant was not provided with access to the defense attorney during the period in police custody. As a result, the Chamber did not find the violation of Article 6, paragraph 3(c) of the ECHR (Salduz v. Turkey, para. 24). Accordingly, when assessing the claims of the applicant and reaching its decision in the case of Salduz v. Turkey, the Chamber did rely on the previous well-established jurisprudence of the ECHR with regard to restricting the access to the defense attorney and the consequences stemming from such restrictions for the rest of proceedings. As a result, the Chamber did not depart from the then-established case-law of the ECtHR according to which the absence of legal assistance occurring during the initial stages of criminal proceedings may be cured afterward provided that the criminal proceedings were fair taken as a whole. 


\subsection{The Judgment of the Grand Chamber}

While the Chamber did not find the violation of the applicants' rights under Article 6, paragraph 3(c) of the ECHR, the Grand Chamber arrived at a different conclusion with regard to access to the defense attorney during the investigation (ECtHR, Salduz v. Turkey, no. 36391/02, Judgment of 27 November 2008 [GC]). The Grand Chamber took the stance that the applicant was undoubtedly affected by the restrictions on his access to the defense attorney in that his statement to the police was used for his conviction. The Grand Chamber held that neither the assistance provided afterward by the defense attorney nor the adversarial nature of the subsequent proceedings could cure the defects which had occurred during police custody (Salduz v. Turkey [GC], para. 58). In addition to the abovementioned, the Grand Chamber gave special weight to the fact that the applicant was a minor at the time of the conduction of the criminal proceedings against him. (Salduz v. Turkey [GC], para. 60). The Grand Chamber further went on to observe that the restriction imposed on the right of access to the defense attorney was systematic and applied to anyone held in police custody, regardless of his or her age provided that a person is charged with an offense falling under the jurisdiction of the State Security Courts (Salduz v. Turkey [GC], para. 61). To sum up, even though the Grand Chamber acknowledged that the applicant was provided with the opportunity to challenge the evidence against him at the trial and subsequently during the appeal proceedings, the Grand Chamber emphasized that the absence of the defense attorney while the applicant was in police custody irretrievably affected his defense rights (Salduz v. Turkey [GC], para. 62).

The two main principles of enormous significance for the legal standing of the accused may be derived from the Salduz doctrine. In the first place, the ECtHR made it clear that any systemic and mandatory statutory restriction as regards the right to access to the defense attorney renders a whole trial unfair. Namely, according to the view of the Grand Chamber expressed in Salduz Judgment, in order for the right to a fair trial to remain sufficiently ,practical and effective“, the provision of Article 6, paragraph 1 of the ECtHR requires that, as a rule, access to the defense attorney should be provided as from the first interrogation of a suspect by the police, unless it is demonstrated in the light of the particular circumstances of each case that there are compelling reasons to restrict this right. To sum up, the Salduz doctrine laid out the rule requiring that the suspect has the right to be provided with access to the defense attorney when the former is subject to questioning on the part of the police (Vamos, 2016: 406). Accordingly, any restrictions of the right of access to the defense attorney in pre-trial proceedings come into play only upon the condition that compelling reasons are justifying the 
subjection of the mentioned right to restrictions under the provisions of respective national criminal procedural legislation. Therefore, the right of access to the defense attorney is susceptible to restrictions on the condition of the existence of compelling reasons. Hence, such an approach adopted on the part of the Grand Chamber narrowed the possibilities of states regarding the restriction of the right to the defense attorney. Namely, the deprivation of the right to access to the defense attorney occurred without the existence of compelling reasons results in the violation of the right to a fair trial. Therefore, following this line of thought, the right to access to the defense attorney under the Salduz doctrine is susceptible to restrictions only in exceptional circumstances. In addition to the above, the Grand Chamber clarified that the existence of compelling reasons does not give states the carte blanche to limit access to the defense attorney. However, in later judgments molded on the basis of the Salduz doctrine, the ECtHR expanded the abovementioned right to the benefit of the accused to other procedural situations arising during pre-trial proceedings. Accordingly, the right of access to the defense attorney arises also during other procedural actions in addition to questioning, such as identification procedures or reconstructions of events (Ibrahim Öztürk v. Turkey, no. 16500/04, paras. 48-49, Judgment of 17 February 2009). Also, in the case of Brusco v. France, the ECtHR removed any doubt about the lawyer's presence at interviews, by holding that the defendant had the right to be assisted by the defense attorney from the beginning of his detention and not only during questioning (ECtHR, Brusco v. France, no. 1466/07, paras. 45-54, Judgment of 14 October 2010). Furthermore, the ECtHR found the violation even when the applicant had remained silent in police custody while being denied the right to the defense attorney (ECtHR, Dayanan v. Turkey, no. 7377/03, para. 33, Judgment of 13 October 2009). For instance, in the case of Dayanan v. Turkey, the ECtHR held that the suspect should not only be assisted by the defense attorney while being questioned but also as soon as he or she is taken into custody to be able to obtain the whole range of services specifically associated with legal assistance, such as discussion of the case, organization of the defense, collection of evidence favorable to the accused, preparation for questioning, support of an accused in distress and checking of the conditions of detention (Dayanan v. Turkey, para. 32).

In the second place, perhaps the most significant implication of the Salduz, not underestimating the others, such as the one examined above, concerns the consequences stemming from depriving the suspect of the right to the defense attorney during pre-trial proceedings in relation to the fairness of criminal proceedings taken as a whole. Even though there is no doubt that the procedural moment when the right to defense attorney arises is of paramount significance for the suspect, this right would remain nothing more than the dead letter of the law 
unless specific procedural consequences aimed at safeguarding the interests of the suspect are triggered by the violation of the right to the defense attorney. According to the Grand Chamber in the case of Salduz v. Turkey, even if the existence of compelling reasons may exceptionally justify denial of access to the defense attorney, such restriction - whatever its justification - must not unduly prejudice the rights of the accused under Article 6 of the ECHR. The Grand Chamber further went on to say that, the rights of the defense will in principle be irretrievably prejudiced when incriminating statements made during police interrogation without access to [the defense attorney] are used for a conviction" (Salduz v. Turkey [GC], para. 55). As a result of prohibiting the use of incriminating statements ${ }^{1}$ made on the part of the suspect when he was deprived of the right to access the defense attorney, the Grand Chamber „construed an absolute, rightsbased, categorical exclusionary rule for confessional evidence“ obtained in such circumstances (Giannoulopoulos, 2019: 168). In this connection, the essence of the Salduz absolute exclusionary rule is summarized by the Dissenting Opinion of Judge Spano in the case of Aras v. Turkey (ECtHR, Aras v. Turkey (no. 2), no. 15065/07, Judgment of 18 November 2014, Dissenting Opinion of Judge Spano). The exclusionary rule derived from the Salduz case was based on ,, a purely automatic application of the requirement of legal assistance under Article 6, paragraph 3(c), without it being deemed necessary to show that the lack of such assistance had a prejudicial effect, even speculatively, on the fairness of the applicant's trial“" (Aras v. Turkey (no. 2), Dissenting Opinion of Judge Spano, para. 2). Thus, the ECtHR made it clear that the Salduz doctrine requires the obligatory exclusion of self-incriminatory statements when it said ,that the most appropriate form of redress for a violation of Article 6, [paragraph] 1 would be to ensure that the applicant, as far as possible, is put in the position in which he would have been had this provision not been disregarded. [...] Consequently, the Grand Chamber consider[ed] that the most appropriate form of redress would be the retrial of the applicant in accordance with the requirements of Article 6 [paragraph] 1 of the [ECtHR],

1 As regards the exclusionary rule under the Salduz doctrine, it is worth emphasizing that the ECtHR in the subsequent case-law has expanded the application of the exclusionary rule to other evidence in addition to directly self-incriminatory statements made when the suspect is deprived of the right to access to the defense attorney. Namely, according to the view of the ECtHR in the case of Begu $v$. Romania, the right not to incriminate oneself cannot reasonably be confined to statements of admission of wrongdoing or to remarks which are directly incriminating. Among others, the ECtHR drew attention to the fact that even testimony obtained under compulsion which appears on its face to be of a non-incriminating nature - such as exculpatory remarks or mere information on questions of fact - may later be deployed in criminal proceedings in support of the prosecution case, for instance, to contradict or cast doubt upon other statements of the accused or evidence given by him during the trial or to otherwise undermine his credibility (ECtHR, Begu v. Romania, no. 20448/02, para. 54, Judgment of 15 March 2011). 
should the applicant so request“" (Salduz v. Turkey [GC], para. 72). In this connection, the previously mentioned rule as regard redress is further clarified in the Joint Concurring Opinion of Judges Rozakis, Spielmann, Ziemele, and Lazarova Trajkovska, who opined that, ,when a person has been convicted in breach of the procedural safeguards afforded by Article 6, he should, as far as possible, be put in the position in which he would have been had the requirements of that Article not been disregarded (the principle of restitutio in integrum) " (ECtHR, Salduz v. Turkey, no. 36391/02, Joint Concurring Opinion of Judges Rozakis, Spielmann, Ziemele, and Lazarova Trajkovska, para. 4). Therefore, in the view of the concurring Judges, the ECtHR ,should seek to restore the status quo ante for the victim“ whenever possible. In this connection, as regards the use of evidence obtained in violating the right to access to the defense attorney, the ECtHR stated that the required redress is the exclusion of such evidence. Consequently, in the Salduz case, despite not defining compelling reasons, the ECtHR left no doubt regarding the legal destiny of criminal proceedings where one of the bases of conviction was a self-incriminatory statement made during police interrogation without access to the defense attorney. Namely, regardless of other circumstances of criminal proceedings, such criminal proceedings always fall short of Article 6 requirements, while evidence obtained in the context of the absence of the defense attorney cannot be used as a basis for conviction with the aim of curing a described violation.

\section{Ibrahim and Others v. the United Kingdom}

\subsection{The Circumstances of the Case}

The Judgment of the Grand Chamber (hereinafter also: the Ibrahim Judgment) handed down in the case of Ibrahim and Others v. the United Kingdom (hereinafter also: the case) has probably been the most controversial decision of the ECtHR in the so-called post-Salduz era (Burić, 2018: 338). The event and surrounding facts giving rise to the case of Ibrahim and others arose in the aftermath of the tragic event attracting attention all around the world. Four suicide bombs exploded on 7 July 2005 on three underground trains and a bus in central London, killing fifty-two people and injuring hundreds more (ECtHR, Ibrahim and Others v. the United Kingdom, nos. 50541/08, 50571/08, 50573/08 \& 40351/09, para. 14, Judgment of 13 September 2016 [GC]). Two weeks later, on 21 July 2005, Mr. Muktar Said Ibrahim, Mr. Ramzi Mohammed, and Mr. Yassin Omar (hereinafter: the first three applicants), and a fourth man, detonated four bombs on three underground trains and a bus in central London. On 23 July 2005, 
a fifth bomb was discovered abandoned and undetonated in a London park. (Ibrahim and Others v. the United Kingdom [GC], para. 15). Even though the four bombs were detonated they did not explode due to the main charge, liquid hydrogen peroxide, failing to explode. (Ibrahim and Others $v$. the United Kingdom [GC], para. 16). The first three applicants and Mr. Osman all ran away from the scenes of their attempted explosions. In the days following the unsuccessful terrorist attack, the four men were arrested, the first three applicants in England between 27 and 29 July and Mr. Osman in Rome, Italy, on 30 July. They stood trial and were convicted for conspiracy to murder (Ibrahim and Others $v$. the United Kingdom [GC], para. 17). Mr. Ismail Abdurahman (hereinafter: the fourth applicant) gave Mr. Osman shelter at his home in London during the period when Mr. Osman was on the run from the police and before he fled to Rome. The police interviewed the fourth applicant in England on 27 and 28 July 2005 and arrested him on the latter date. In separate proceedings, he was tried and convicted of assisting Mr. Osman and failing to disclose information after the event (Ibrahim and Others v. the United Kingdom [GC], para. 18). In this connection, it is worth stressing that the safety interviews were undertaken in relation to the first three applicants. These interviews were conducted „for the purpose of protecting life and preventing serious damage to property", and, in accordance with the relevant national legislation in force at that time, police authorities were allowed to restrict the right to legal assistance up to 48 hours if needed (Ibrahim and Others v. the United Kingdom [GC], para. 23). Even though the first three applicants had requested to be provided with legal assistance, the police did not honor their requests on the following two grounds in view of the fact that ,delaying the interview would involve an immediate risk of harm to persons or damage to property" and that ,legal advice would lead to the alerting of other people suspected of having committed offenses but not yet arrested" (Ibrahim and Others v. the United Kingdom [GC], paras. 21-22, 28, 39-41, 43, 49-50, 51).

The applicants complained that their rights under Article 6, paragraphs 1 and 3(c) were violated in view of the fact they had been interviewed by the police without access to the defense attorney and that statements made in those interviews had been used at their trials (Ibrahim and Others v. the United Kingdom [GC], para. 5). The first three applicants argued that the Salduz doctrine imposed a bright-line rule prohibiting the use at trial of statements obtained during police interrogation in the absence of the defense attorney, which is a rule also applied in terrorism cases. (Ibrahim and Others v. the United Kingdom [GC], para. 236). They argued that there were no compelling reasons to restrict their right to the defense attorney and that even the undisputable gravity of the allegations could not alone justify a restriction. In their view, the absence of compelling reasons 
was sufficient in and of itself to result in a violation of Article 6, paragraphs 1 and 3(c) (Ibrahim and Others v. the United Kingdom [GC], para. 237). In any event, they argued that the restriction on legal advice had led to undue prejudice in their cases. (Ibrahim and Others v. the United Kingdom [GC], para. 238). The fourth applicant complained that his guilt was established on the basis of the self-incriminating statement he had made as a witness, and therefore without having been notified of his privilege against self-incrimination or having been provided with access to the defense attorney (Ibrahim and Others v. the United Kingdom [GC], para. 295). Namely, the police initially treated the fourth applicant as a witness and, in that capacity, he was invited to the police station to assist with the investigation where he gave a self-incriminatory statement later used for his conviction (Ibrahim and Others v. the United Kingdom [GC], paras. 137-180, 296).

\subsection{The Compelling Reasons}

The Grand Chamber in the Ibrahim case employed the test set out in Salduz when establishing whether there was the violation of the right derived from Article 6, paragraph 3(c) of the ECtHR while admitting that the Salduz test needs clarification, especially in relation to the meaning of compelling reasons (Celiksoy, 2018: 234). Namely, according to the view of the Grand Chamber expressed in the Ibrahim Judgment, the Salduz test is two-tiered, considering that this test comprises two stages applied in a particular sequence (Ibrahim and Others v. the United Kingdom [GC], paras. 257-262). In this connection, when assessing whether the deprivation of access to the defense attorney resulted in the violation or the right to a fair trial, the ECtHR must evaluate, in the first stage of the Salduz test, whether there were compelling reasons for the restriction (Ibrahim and Others $v$. the United Kingdom [GC], paras. 257-262). Afterward, in the second stage of the Salduz test, the ECtHR must evaluate the prejudice caused to the rights of the defense by the restriction in the case in question. In other words, the ECtHR must examine the impact of the restriction on the overall fairness of the proceedings and decide whether the proceedings as a whole were fair (Ibrahim and Others $v$. the United Kingdom [GC], para. 257).

The Grand Chamber accepted the claim of the Government that there were compelling reasons for the temporary restrictions on the first three applicants' right to legal advice arising from the potential for loss of life on a large scale, the urgent need to obtain information on planned attacks, and the severe practical constraints under which the police were operating. The Grand Chamber opined that compelling reasons may exist where an urgent need to avert serious adverse 
consequences for life, liberty, or physical integrity has been convincingly made out. The ECtHR made it clear that there is no doubt that such a need existed at the time when the safety interviews of the first three applicants were conducted, considering that in suicide attacks on three underground trains and a bus two weeks earlier, fifty-two people had been killed and countless others injured (Ibrahim and Others v. the United Kingdom [GC], paras. 276, 279).

Turning to the issue of restricting the right to the defense attorney, the Grand Chamber in Ibrahim case came to the following observations when it comes to compelling reasons as the ground for restricting the mentioned right (Vamos, 2016: 407): 1) restrictions are only permissible in exceptional circumstances, have to be of a temporary nature and have to be based on an individual assessment of the circumstances of the case; 2) in assessing whether compelling reasons exist, it is of relevance that there is a legal basis in domestic law for restricting the right and this legal basis specifies the scope and content of the restriction in order to guide decision-making by the authorities responsible; 3 ) the compelling nature must be assessed on a case-by-case basis; 4) "the urgent need to avert serious adverse consequences for life, liberty or physical integrity in a given case can amount to compelling reasons to restrict access to legal advice for purposes of Article 6" (Ibrahim and Others v. the United Kingdom [GC], paras. 258-259); 5) a non-specific risk of leaks susceptible of jeopardizing the investigation arising from legal assistance cannot constitute compelling reasons (Ibrahim and Others v. the United Kingdom [GC], para. 259). Thus, it is worth observing that the existence of a substantive condition expressed in the existence of compelling reasons does not justify the restriction of legal advice in itself, considering that Article 6 of ECHR requires a procedural assessment of the compelling reasons to have been made with the aim of demonstrating such existence on the basis of contemporaneous evidence (Ibrahim and Others v. the United Kingdom [GC], paras. 258, 277, 300; Vamos, 2016: ibid.; Celiksoy, 2018: 234-239).

As we have seen, the Judgment of the Grand Chamber handed down in the case of Ibrahim and Others v. the United Kingdom does not affect the temporal scope of the right to access legal advice. In fact, by relying on the autonomous understanding of the term charge, the Grand Chamber clarified that the right to the defense attorney does not arise from the time of the first interrogation, that is when the person is formally presented with charges, but from the time of the carrying out the first action on the part of authorities conducting the process that is aimed to prosecute the person (Sakowicz, 2021: $2004 \mathrm{fn.} \mathrm{53).} \mathrm{Nonetheless,} \mathrm{on} \mathrm{the}$ other hand, in contrast to the Salduz Judgement, the Ibrahim Judgment opens far more leeway for states to restrict the right of the suspect to the defense attorney during pre-trial proceedings. In other words, while the right of the suspect to have 
the defense attorney during the investigation remains intact according to the reasoning of the Ibrahim Judgment, this right may be the subject of certain restrictions based upon fulfilling substantive and procedural requirements depending on the particulars of each specific case. To put it simply, the issue stemming from Ibrahim is not when the right to the defense attorney arises during criminal proceedings, but whether this right is susceptible to restriction under national legislation and which consequences follow from the violation of this right for criminal proceedings as a whole. In this regard, the two critiques may be attributed to the reasoning of the Grand Chamber as for the understanding and application of the notion of compelling reasons.

In the first place, it may be said that it is questionable whether the understanding of the meaning of compelling reasons as a ground for legitimizing restricting the fair trial rights in the Ibrahim case is in line with the previous jurisprudence of the ECtHR. Even though there is no doubt that the provisions of Article 6 are susceptible to derogation in the time of war or other public emergency threatening the life of the nation of any High Contracting Party (Article 15, paragraph 1), it is not clear whether public or other overriding interests may allow the legitimate restriction of the fair trial rights resulting in making these rights qualified in other circumstances (Goss, 2014: 116-118, 176-201). Namely, according to some viewpoints in this respect, neither the ECHR nor the jurisprudence of the ECtHR implies that the rights derived from Article 6 can be simply set aside for public policy or other consequentialist reasons, on the basis that such restrictions are proportionate (Ashworth, 2007: 215). In this connection, in many cases, the ECtHR has sent a clear message refusing to employ public or other overriding interests for the purpose of the legitimization of the restriction of fair trials that would allow the restrictions to occur but not the violations of these rights (Goss, 2014: 178-183). In the case of Teixeira de Castro $v$ Portugal concerning the fight against drug trafficking, the ECtHR stressed that ,the right to a fair administration of justice [...] holds such a prominent place that it cannot be sacrificed for the sake of expedience" while rejecting the use of the public interest as a justification for the use of evidence obtained as a result of police incitement (ECtHR, Teixeira de Castro v Portugal, no. 25829/94, para 36, Judgment of 9 June 1998, Reports of Judgments and Decisions 1998-IV). Also, in the case Hulki Güneş v. Turkey, despite acknowledging the undeniable difficulties modern states are facing in combating terrorism, especially with regard to obtaining and producing evidence - and of the ravages caused to society by this problem, on the one hand, the ECtHR firmly stated that ,such factors cannot justify restricting to this extent the rights of the defense of any person charged with a criminal offense“, one the other hand (ECtHR, Hulki Güneş v. Turkey, no. 28490/95, para. 96, 
Judgment of 19 June 2003, Reports of Judgments and Decisions 2003-VII). In addition to the above, the ECtHR left no doubt that even the fact that the person is charged with a most heinous criminal offense, such as crimes against humanity, does not allow that the interest of efficiency of the criminal proceedings supersedes the procedural safeguards derived from the right to a fair trial. For instance, when the Government attempted to justify the restriction to access to the defense attorney by drawing attention to the fact the applicant was tried and convicted of crimes against humanity, in rejecting the gravity of the offenses as a basis for restricting the abovementioned right, the ECtHR opined that ,the fact that the applicant was prosecuted for and convicted of aiding and abetting crimes against humanity does not deprive him of the guarantee of his rights and freedoms under the [ECHR]" (ECtHR, Papon v. France, no. 54210/00, paras. 71, 84, 90, 98, Judgment of 25 July 2002). Last but not least, the previously mentioned reluctance of the ECtHR to take into account public interest considerations as a basis for undermining fair trial rights is obvious when having in mind the opinion of the Grand Chamber in the Salduz case when the ECtHR said that (Goss, 2014: 182) ,it is in the face of the heaviest penalties that respect for the right to a fair trial is to be ensured to the highest possible degree by democratic societies“(Salduz v. Turkey [GC], para. 50). Therefore, the cited paragraph may be interpreted in the sense that the procedural safeguards applied in a particular case should grow proportionally to the gravity of the charge, that is, the seriousness of the concerned criminal offenses.

When reading the Ibrahim Judgment, at first glance, it seems that the ECtHR remained faithful to the status of the right to a fair trial as an unqualified right. In the Ibrahim case, the Grand Chamber clarified that the general requirements of fairness derived from Article 6 apply to all criminal proceedings, regardless of the type of offense in the issue. Moreover, the Grand Chamber made it clear that ,, $[\mathrm{t}]$ here can be no question of watering down fair trial rights for the sole reason that the individuals in question are suspected of involvement in terrorism. In these challenging times, the [ECtHR] considers that it is of the utmost importance that the Contracting Parties demonstrate their commitment to human rights and the rule of law by ensuring respect for, inter alia, the minimum guarantees of Article 6 of the [ECHR]" (Ibrahim and Others v. the United Kingdom [GC], para. 252). Nonetheless, despite categorically stating that the gravity of criminal offenses cannot be the sole reason for watering down fair trial rights, the Grand Chamber went back on its own words in this sense by saying that ,when determining whether the proceedings as a whole have been fair the weight of the public interest in the investigation and punishment of the particular offense in issue may be taken into consideration". In addition, the Grand Chamber further took an explicit stance according to which the application of fair trial rights should not ,put disproportionate difficulties 
in the way of the police authorities in taking effective measures to counter terrorism or other serious crimes in the discharge of their duty under Articles 2, 3, and 5 paragraph 1 of the [ECHR] to protect the right to life and the right to bodily security of members of the public". Finally, the Grand Chamber held that taking measures that extinguish the very essence of fair trial rights cannot be justified by invoking public interest concerns (Ibrahim and Others v. the United Kingdom [GC], para. 252). Thus, having in mind the above considerations, one can easily observe the inconsistency of the Grand Chamber with regard to the unclear status of the fair trial rights in the sense of whether these rights are unqualified or qualified. Considering that the majority in the Ibrahim case devoted a great deal of attention to substantive and procedural requirements for the restriction of the fair trial rights while acknowledging that the application of the fair trial rights should not hamper the activities of police and other law enforcement authorities when they are suppressing and prosecuting serious criminal offenses, such as terrorism, the Grand Chamber endangered the status of Article 6 as unqualified. Namely, as Judges Sajo and Laffranque correctly observed in their Joint Partly Dissenting, Partly Concurring Opinion, the Judgment of the Grand Chamber in the Ibrahim case deviated ,from the noble principle announced, and indeed the [majority] itself water[ed] down rights, by failing to adhere to the guarantees of Article 6 as interpreted in its own well-established case-law, and without expressly stating it, de facto depart[ed] from that earlier well-established case-law, which has been widely applied by the national courts. This is most disappointing" (Ibrahim and Others. $v$ the United Kingdom [GC], Joint Partly Dissenting, Partly Concurring Opinion of Judges Sajo and Laffranque, para. 2). As a result of such approach of the Grand Chamber, the status of Article 6 as unqualified hangs in the balance since the majority in the Ibrahim case attempted to reconcile the two irreconcilable requirements: on the one hand, the majority initially declared that Article 6 rights are unqualified rights not susceptible to watering down when a particularly serious offense is involved, while immediately thereafter acknowledging that Article 6 rights may be set aside with the aim of pursuing the public interest when terrorism is concerned, on the other hand (Goss, 2017: 1149).

In the second place, the Grand Chamber did not provide a concrete explanation as to why it was necessary to restrict the right of the first three applicants to access the defense attorney when they were subjected to safety interviews on the part of the police. It is not difficult to agree with the finding of the Grand Chamber that the overriding priority of the police was gathering information on any further planned attacks and the identities of those potentially involved in the plot. In this connection, according to the view of the Grand Chamber, in relation to the first three applicants, there was the existence of an urgent need to avert serious adverse 
consequences for the life and physical integrity of the public (Ibrahim and Others. v. the United Kingdom [GC], para. 276). However, the Grand Chamber in its reasoning failed to address the issue of how and why delaying the right to legal assistance as for the first three applicants contributed to fulfilling the aims of preventing further terrorist attacks or which security objectives were needed to be achieved that would have required restricting their right to the defense attorney (Burić, 2018: 346-347). Namely, as Judges Sajó and Laffranque said in their separate opinion in which they stated that, ,the fact that there is an urgent need to save lives does not explain why and how the advice and presence, in particular, of [the defense attorney], that is, of a right, would, as a matter of principle, be detrimental to saving lives" (Ibrahim and Others. $v$ the United Kingdom [GC], Joint Partly Dissenting, Partly Concurring Opinion of Judges Sajo and Laffranque, para. 21). Therefore, in other words, in addition to acknowledging the existence of compelling reasons, the Grand Chamber should have clearly elaborated why these reasons in the present case justified restricting the right to legal assistance as for the first three applicants. This shortcoming of the Grand Chamber Judgment in this sense is easily observed when the following is taken into account. Namely, when examining the situation of one of the applicants, that of Mr. Ibrahim, with regard to the existence of compelling reasons, the Grand Chamber justified him being denied of the right to the defense attorney in view of the fact that police operated under a great deal of pressure, that during such a high-intensity situation is not unusual that minor breakdowns in communication occur, that the police needed to invest their maximum effort in conducting investigations and interviews and that therefore the police „cannot be criticized for having failed to realize that there was a small opportunity in which a consultation room with a telephone socket was available and in which Mr. Ibrahim could therefore have been afforded access to a lawyer by telephone“. Additionally, the Grand Chamber also observed that in the same police station when Mr. Ibrahim was held, there were eighteen detainees arrested in connection with the attempted bombings and, all of whom had to be detained separately to avoid communication and cross-contamination of forensic evidence (Ibrahim and Others $v$. the United Kingdom [GC], para. 278). In this connection, it may be said that the right to access to the defense attorney in relation to Mr. Ibrahim was denied because of the objective conditions in the police station and the fact that the police operated under pressure, but not because of the fact that the exercise of his right to be provided with legal assistance would pose a threat to overriding interests or endanger the investigation or the prevention of other terrorist attacks. Therefore, the Grand Chamber did not follow its own standard requiring a case-by-case basis assessment of the existence of compelling reasons since the Grand Chamber did not undertake the assessment of each applicant's situation 
with regard to the restriction of the right of access to the defense attorney as for the first three applicants (Celiksoy, 2018: 236). Accordingly, in light of the above considerations, it seems that for the ECtHR is enough that the exceptional circumstances requiring achieving overriding aims, such as preventing harm to life and limb of others, exist and that the suspect may be placed in some broader context related to satisfying the criterion of compelling reasons. However, such an approach literally amounts to a general ban on the right to access to the defense attorney since it could extend to dozens or even many more suspects in a hypothetical case which would clearly contradict the Salduz doctrine.

\subsection{The Fairness of the Proceedings as a Whole Test}

After acknowledging the existence of compelling reasons justifying the restriction of the right to the defense attorney with regard to the first three applicants, the Grand Chamber went on to assess the fairness of the proceedings as a whole in the Ibrahim case. However, it is worth observing that the Grand Chamber took the view the that Salduz test is always the two-stage test; therefore, regardless of the non-existence of compelling reasons with regard to restricting access to the defense attorney, it is necessary to assess whether the criminal proceedings as a whole were fair or not. In assessing whether the criminal proceedings in relation to the first three applicants were overall fair and whether the violation of their rights under Article 6 occurred, the Grand Chamber took into account a number of factors. In this connection, the Grand Chamber observed that the possibility of restricting access to the defense attorney had been based on the national legislation, as well as that ,the police adhered strictly to the legislative framework which regulated how they had to conduct their investigation" (Ibrahim and Others v. the United Kingdom [GC], para. 281). In addition to the abovementioned, the Grand Chamber drew attention to the fact the first three applicants were at trial entitled to challenge the disputed statements they made in the absence of the defense attorney while having the opportunity to present evidence in their favor (Ibrahim and Others v. the United Kingdom [GC], paras. 282-283). Hence, albeit the statements contested on the part of the applicants were declared as admissible, the applicants had the right to challenge these statements at trial (Ibrahim and Others v. the United Kingdom [GC], para. 283). Moreover, the applicants subsequently requested the exclusion of the evidence again before the Court of Appeal in support of their argument that the admission of the evidence had rendered the trial unfair and that their convictions should be quashed (Ibrahim and Others v. the United Kingdom [GC], para. 284). Besides, in the further examination of the fairness of the criminal proceedings against the first 
three applicants, the Grand Chamber noticed that „the statements were merely one element of a substantial prosecution case against the applicants", the quality of directions which the trial judge gave to the jury, and lastly the strength of the public interest in the investigation and punishment of the offenses in question (Burić, 2018: 349). In the end, the Grand Chamber concluded that the proceedings as a whole in respect of each applicant were fair regardless of the delay in affording the first three applicants' access to legal advice and the admission at trial of statements made in the absence of legal advice. As a result, the Grand Chamber did not find the violation of Article 6, paragraphs 1 and 3(c) of the ECHR (Ibrahim and Others v. the United Kingdom [GC], para. 294).

As earlier said, the circumstances surrounding the case of the fourth applicant differ from those of the first three applicants. In this connection, the Grand Chamber did not find the existence of compelling reasons on the side of the fourth applicant. However, this fact does not automatically lead to the whole criminal proceedings being rendered unfair in relation to the fourth applicant according to the view of the Grand Chamber in the Ibrahim case. Namely, when compelling reasons for the restriction of the right to legal advice do not exist, „the burden of proof shifts to the Government to demonstrate convincingly why, exceptionally and in the specific circumstances of the case, the overall fairness of the trial was not irretrievably prejudiced by the restriction on access to legal advice" (Ibrahim and Others v. the United Kingdom [GC], para. 301). With regard to the fourth applicant, the Grand Chamber observed that the decision to continue questioning the fourth applicant as a witness was without basis in domestic legislation and was contrary to the guidance given in the applicable code of practice. Namely, the failure to treat him as a suspect resulted in depriving the fourth applicant of the notification of his procedural rights since such a notification, pursuant to domestic law, is triggered by a decision that a person is suspected of an offense. In the view of the Grand Chamber, treating the fourth applicant as a witness constituted, in itself, a shortcoming in terms of the guarantees afforded by Article 6, which, among other things, include the right to be notified of one's privilege against self-incrimination. The Grander Chamber further emphasized that it was a particularly significant defect in the case in question, where the applicant was deprived of the right to access to the defense attorney who could have informed him of his rights, and the Government did not provide a convincing justification for such information (Ibrahim and Others v. the United Kingdom [GC], para. 303).

Given that the ECtHR has replaced ,the automatic exclusionary rule" introduced by Salduz with ,the proceedings as a whole test“, there is no doubt that the ECtHR has done away with the main tenet of the Salduz doctrine, according to which the restrictions of the right to access to the defense attorney regardless of their 
justification must not unduly prejudice the rights of the accused under Article 6 of the ECtHR (Soo, 2017: 335). Namely, the ECtHR in the Salduz case held that the use of incriminating statements made when the suspect is deprived of the right to access to the defense attorney as a basis for conviction automatically leads to the violation of the right to a fair trial (Salduz v. Turkey [GC], para. 55). In this connection, a precise critique of the Ibrahim Judgment is offered on the part of non-governmental organization Fair Trials International (hereinafter: FTI) acting as the third-party intervener in the case of Beuze v. Belgium (ECtHR, Beuze v. Belgium, no. 71409/10, paras. 108-113, Judgment of 9 November 2018 [GC]). Among others, FTI contended that the Judgment in the Ibrahim case had departed from the postSalduz doctrine by asserting that, even in cases where their compelling reasons did not exist, ,there was no reason in principle why such statements should not be used for a conviction, provided that the overall fairness of the proceedings was not affected" (Beuze v. Belgium [GC], para. 111). In addition to the above, the critique of the Ibrahim Judgement in the context of the substitution of the absolute exclusionary rule with the overall fairness test may be well-complemented with the Joint Concurring Opinion of Judges Kalaydjieva, Pinto de Albuquerque, and Turković, in the 2015 case of Dvorski v Croatia (ECtHR, Dvorski v. Croatia [GC], no. 25703/11, Judgment of 20 October 2015, Joint Concurring Opinion of Judges Kalaydjieva, Pinto de Albuquerque, and Turković). These judges started with the premise that ,[i]n criminal procedure, there are some procedural rights so basic to a fair trial that their infringement can never be viewed as fair. The infringement of these rights results in a structural error, which affects the framework within which the trial proceeds“ (Dvorski v. Croatia [GC], Joint Concurring Opinion of Judges Kalaydjieva, Pinto de Albuquerque, and Turković, para. 16). The right to legal assistance provided on the part of the defense attorney is such a right. Namely, as FTI emphasized as the third-party intervener in the case of A.T. v. Luxembourg, the right to the defense attorney is a fundamental guarantee facilitating the exercise of other procedural rights and extending beyond preventing suspects from confessing to the offense (ECtHR, A.T. v. Luxembourg, no. 30460/13, para. 58, 9 Judgment of April 2015). In this connection, it should be kept in mind that ensuring prompt access to the defense attorney decisively contributes to the lessening of the vulnerability of suspects in police custody, providing a fundamental safeguard against coercion and ill-treatment of suspects by the police and contributing to the prevention of miscarriages of justice and the fulfilment of the aims of Article 6, especially the equality of arms between the investigating or prosecuting authorities and the accused (Ibrahim and Others $v$. the United Kingdom [GC], para. 255). After all, the natural and objective inequality between the prosecutor and the suspect is most pronounced during the investigation because of an asymmetry in power and resources between 
the former and the latter (Sidhu, 2017: 222). Turning back to Joint Concurring Opinion in the case of Dvorski v. Croatia, the Concurring Judges captured the essence of the categorical exclusionary rule as a remedy for the violation of the right to access to the defense attorney introduced with the Salduz case (Giannoulopoulos, 2019: 196) by saying that the Salduz doctrine ,introduced an automatic exclusionary rule for self-incriminatory statements obtained without [the defense attorney] being present during questioning when there were no compelling reasons for denying access to [the defense attorney], that is, in situations of unjustified denial of access to [the defense attorney])“ (Dvorski v. Croatia [GC], Joint Concurring Opinion of Judges Kalaydjieva, Pinto de Albuquerque, and Turković, para. 17). The Concurring Judges in the same case drew attention to the fact the exclusionary rule plays a vital role in the protection of the privilege against self-incrimination, and that the use of evidence collected in breach of this basic privilege will always render a trial unfair, irrespective of any other circumstances of the case. In their view, for this reason, the ECtHR held in the Salduz that basing any conviction on an admission or statement given in the violation of the right of access to the defense attorney constituted the violation of the general right to a fair trial guaranteed under Article 6, paragraph 1 of the ECtHR (Dvorski v. Croatia [GC], Joint Concurring Opinion of Judges Kalaydjieva, Pinto de Albuquerque, and Turković, para. 17). However, in reaching the decision in the Ibrahim case, instead of focusing on the fact that self-incriminatory statements were used as a basis for convicting the applicant, whereby such statements were made in the absence of the defense attorney, the ECtHR invented a test under which numerous non-exhaustive factors are relevant for the fairness of the proceedings as a whole, while none of the factors taken into account is decisive (Giannoulopoulos, 2019: 196). Therefore, as FTI correctly pointed out in the capacity of the third-party intervener in the Beuze case, a more flexible approach adopted by the Ibrahim court allowed the legitimization of situations in which the use of evidence obtained in the absence of the defense attorney was tolerated. As a result, the application of the Ibrahim test - a discretionary substantive assessment based on the numerous non-exhaustive factors opens space for varying interpretations and results (Beuze v. Belgium [GC], para. 112).

\section{Beuze v. Belgium}

\subsection{The Circumstances of the Case}

The erosion of the Salduz doctrine has not ended with the Judgment of the Grand Chamber delivered in the case of Ibrahim and Others v. the United Kingdom; on the contrary, the Judgment of the Grand Chamber handed down in the case of 
Beuze v. Belgium (hereinafter also: the Beuze case, the Beuze Judgment) stroke another blow to the doctrine originating from the Salduz case (Celiksoy, 2019; Goss, 2019). In this connection, it is worth observing that the circumstances surrounding the Beuze case are similar to those of the Salduz case. Namely, Mr. Philippe Beuze (hereinafter: the applicant) complained that his rights under Article 6, paragraphs 1 and 3(c) were violated in view of the fact the defense lawyer had not been present when he had been questioned on 31 December 2007 by the Belgian police, while in police custody, and later by the investigating judge (Beuze v. Belgium [GC], para. 92). Besides complaining that he had been deprived of access to the defense attorney while in police custody, the applicant further complained that even once he had been able to consult with a lawyer, his lawyer could not assist him during his police interviews or examinations by the investigating judge or attend a reconstruction of events (Beuze v. Belgium [GC], para. 115). According to the view of the applicant, the denial of access to the defense attorney stemmed from the application of Belgian law, which, at the time of the proceedings against him, did not satisfy the requirements of the case-law of ECtHR as it did not, on account of the secrecy of the judicial investigation, grant legal assistance to the person in custody until after the investigating judge's decision on pre-trial detention (Beuze v. Belgium [GC], para. 92). Therefore, as in the Salduz case, the law applied to the applicant at the time of the criminal proceedings put in place a systematic, general, and mandatory restriction concerning the right to access to the defense attorney during the initial stages of criminal proceedings.

\subsection{The Judgment of the Grand Chamber}

The Grand Chamber did not dispute that the impugned restrictions in force at the time depriving the applicant of the right to legal assistance stemmed from the lack of provision in the Belgian legislation and the interpretation of the law by the domestic courts (Beuze v. Belgium [GC], para. 160). The Grand Chamber reiterated that restrictions on access to the defense attorney based on the existence of compelling reasons, at the pre-trial stage, are permitted only in exceptional circumstances, must be of a temporary nature, and must be based on an individual assessment of the particular circumstances of the case. The Grand Chamber further clarified that there was clearly no such individual assessment in the present case, as the restriction was one of a general and mandatory nature (Beuze v. Belgium [GC], para. 161). Moreover, the Grand Chamber said that the Government did fail to demonstrate the existence of any exceptional circumstances which could have justified the restrictions on the applicant's rights (Beuze v. Belgium 
[GC], para. 163). However, in relying on the Ibrahim case, the ECtHR also made it clear that the absence of compelling reasons did not automatically result in the violation of Article 6. Namely, whether or not there are compelling reasons, it is necessary in each case to view the proceedings as a whole. The ECtHR also drew attention to the fact that in the Ibrahim judgment, followed by the Simeonovi ${ }^{2}$ judgment, the ECtHR rejected the argument of the applicants in those cases that the Salduz rule meant that restricting the right to the defense attorney without compelling reasons leads to the violation of the right to a fair trial (Beuze v. Belgium [GC], para. 144). According to the view of the majority in the Beuze case, in the absence of compelling reasons, the ECtHR must apply very strict scrutiny when conducting fairness assessment. In such a case, the burden of proof will then shift on the Government to demonstrate convincingly why, exceptionally and in the specific circumstances of the case, the overall fairness of the criminal proceedings was not irretrievably prejudiced by the restriction on access to the defense attorney (Beuze v. Belgium [GC], para. 145).

Even though the Grand Chamber did find the violation of Article 6, paragraph 3(c) of the ECHR, the reasoning of the Grand Chamber sparked off controversy (Celiksoy, 2019; Goss, 2019). What is more, even the four Judges comprising the Grand Chamber in the Beuze case expressed strong disagreements with the reasoning of the Grand Chamber in the Beuze Judgment, despite voting together with their colleagues in finding the violation of Article 6, paragraph 1 and 3(c) of ECHR (Beuze v. Belgium [GC], Joint Concurring Opinion of judges Yudkivska, Vučinić, Turković and Hüseynov). According to the views of the concurring Judges, the Grand Chamber departed from the standards of a fair trial developed in Salduz and Ibrahim and Others, taken together, under the guise of interpreting them. The concurring Judges also held that the Judgment of Grand Chamber in the case of Beuze and Belgium distorted and changed the Salduz principle and devalued the right previously established on the part of the ECtHR (Beuze v. Belgium [GC], Joint Concurring Opinion of judges Yudkivska, Vučinić, Turković and Hüseynov, para. 19). Namely, under the Salduz doctrine access to the defense attorney should be provided as from the first interrogation of the

2 In the case of Simeonovi v. Bulgaria, as a result of applying the principles from Ibrahim as for the assessing of the fairness of the criminal proceedings as a whole, the Grand Chamber did not find the violation of the right to a fair trial despite the fact the applicant was deprived of the right to legal assistance for three days while remanded in police custody (ECtHR, Simeonovi v. Bulgaria, no. 21980/04, paras. 132-145, Judgment of 12 May 2017 [GC]). In the same case, the Grand Chamber reiterated the reversion of the Salduz doctrine from the Ibrahim Judgement that the violation of Article 6, paragraphs 1 and 3(c) does not arise automatically because of restricting access to the defense attorney in the absence of ,compelling reasons" that would justify such a restriction (Simeonovi v. Bulgaria $[\mathrm{GC}]$, para. 118). 
suspect by the police or other authorities of criminal procedure. Therefore, according to the case of Salduz v. Turkey, access to the defense attorney is a rule required by Article 6 susceptible to restrictions only on the basis of the existence of compelling reasons justifying the restriction of this right in the light of the particular circumstances of each case (Salduz v. Turkey [GC], para. 55). The concurring judges opined that , [t] $[$ he Beuze judgment in this respect represents a regrettable counter-revolution: it has overruled the ,as a rule“ requirement - already repeated in more than one hundred judgments widely known as the „Salduz jurisprudence" - and has dramatically relativized it to the detriment of procedural safeguards" (Beuze v. Belgium [GC], Joint Concurring Opinion of judges Yudkivska, Vučinić, Turković and Hüseynov, para. 25). The Salduz rule in this regard is exemplified in the case of Dayanan v. Turkey when a systematic restriction under which the applicant did not have legal assistance while in police custody because it was not possible under the law then in force, that is, the automatic restriction taking place on the basis of the relevant statutory provisions, is sufficient in itself for the violation of Article 6 to occur, notwithstanding the fact whether the applicant remained silent or not when questioned in police custody (Dayanan v. Turkey, para. 33). ${ }^{3}$ Moreover, the case of Borg v. Malta further epitomized the essence of the Salduz rule according to which the suspect should be provided the right to access the defense attorney in the initial stages of criminal proceedings. Namely, in the concerned case, the ECtHR took the stance that a systemic restriction applicable to all accused persons deprived the applicant of the right to legal assistance at the pre-trial stage which meant that this already fell short of the requirements of Article 6 under which the right to assistance of the defense attorney at the initial stages of police interrogation may only be subject to restrictions if there are compelling reasons. Accordingly, in the case of Borg v. Malta, in following the Salduz doctrine, the ECtHR confirmed that there is no need to examine the overall fairness of criminal proceedings or the existence of compelling reasons if the denial of the right to the defense attorney resulted from a general statutory restriction based upon applicable national legislation (ECtHR, Borg $v$.

3 In contrast to the case of Dayanan v. Turkey, in the case of Zherdev v. Ukraine, in following the Ibrahim standard of the overall fairness assessment, albeit the applicant, a particularly vulnerable person as a minor and a detainee at the time, was questioned without the presence of the defense attorney, the ECtHR did not find the violation of fair trial rights since it had established that the courts acting in the case did not rely on an admission made in the absence of the defense attorney as a basis for convicting the applicant. The ECtHR also gave weight to the fact that the applicant was positioned during the criminal proceedings to cast doubt on the authenticity of the incriminating evidence at the trial, that the applicant did not retract his guilty plea, and that there was other conclusive evidence determining the conviction (ECtHR, Zherdev v. Ukraine, no. 34015/07, 149151, 161-169, Judgment of 27 April 2017). 
Malta, no. 37537/13, paras. 62-63, Judgment of 12 January 2016). Accordingly, in the Judgment handed down in the case of Beuze v. Belgium, the Grand Chamber did not proceed on the earlier assumption derived from the Salduz doctrine according to which a restriction on access to the defense attorney of a systemic nature (i.e. where national legislation prohibits contact between the suspect and the defense attorney) results in automatic violation of Article 6, paragraphs 1 and 3(c) of the ECHR (Sakowicz, 2021: 2006). Thus, according to the Beuze Judgment, even if there is a systematic, general, and mandatory statutory restriction with regard to access to the defense attorney not accompanied by the existence of compelling reasons, which would result in the automatical violation of the right to a fair trial under the Salduz doctrine, hypothetically speaking, under the view of the Grand Chamber in the Beuze case, criminal proceedings in which such a violation occurred may still be regarded as a fair one on the condition that such criminal proceeding satisfies an assessment of the overall fairness of the proceedings. As a result, the right to access to the defense attorney is no longer a rule under the Beuze Judgment since even a systematic statutory restriction of a general and mandatory nature in relation to the right to the defense attorney will not in itself constitute a violation of Article 6, paragraph 3(c) of the ECHR (Celiksoy, 2019: 18). ${ }^{4}$

\section{Conclusion}

Having in mind the above analysis of the jurisprudence of ECtHR with regard to the right to access to the defense attorney during the initial stages of criminal proceedings and the consequences of restricting this right, there is no doubt that the ECtHR has overturned the Salduz doctrine in the case of Ibrahim and Others v. the United Kingdom, as well as in the later case of Beuze v. Belgium. Namely, both of the two most prominent tenets of the Salduz Judgment - the right to the defense attorney as a rule during the initial stages of criminal proceedings and the automatic exclusionary rule as a proper redress for the violation of the first rule - are a thing of the past.

The first of these rules stemming from the Salduz doctrine to be eroded was the second one. As for the second rule, it is worth observing that the automatic

4 In the case of Doyle v. Ireland, decided after the Beuze case, the ECtHR took the categorical stance that the Salduz doctrine did not establish an absolute rule under which the statutory and systematic origin of a restriction on the right of access to the defense attorney in the absence of compelling reasons leads to requirements of Article 6 to have been breached (ECtHR, Doyle v. Ireland, no. 51979/17, para. 76, Judgment of 24 May 2019). In so doing, the ECtHR confirmed the disappointing view of the Grand Chamber in the Beuze case that opens the door to a systemic and general restriction of the right to the defense attorney in the long run. 
exclusionary rule has been superseded with the proceedings as a whole test or the test of overall fairness constructed in the Ibrahim case to the detriment of the accused. Namely, according to the Ibrahim test, a plethora of factors affects the fairness of criminal proceedings, while none of these factors is of a conclusive nature for fairness in general. Thus, evidence obtained in the context when the suspect is deprived of the right to defense attorney may still be used as a basis for a conviction provided that criminal proceedings were fair as a whole. Furthermore, according to the view of the majority comprising the Grand Chamber in the Ibrahim case, even though fair trial rights as supposedly unqualified ones must not be susceptible to diluting, the application of these rights should not hamper law enforcement authorities when the latter are discharging their duties directed against those suspected of committing serious criminal offenses. Besides, the way the Grand Chamber employed the criterion of compelling reasons as the justification of restricting the right to the defense attorney is tantamount to a general ban, considering that the Grand Chamber did not carry out a case-by-case assessment of the situation of each applicant even though such an approach is required by the test devised on the part of the Grand Chamber itself in the Ibrahim case.

As for the first rule, it is worth emphasizing that the right to the defense attorney as a rule during the initial stages of criminal proceedings was abolished in the Beuze case. Namely, according to the Salduz doctrine and the subsequent jurisprudence drawn upon the former, a systematic denial of the right to access to the defense attorney of a mandatory nature leads to the violation of fair trial rights. On the contrary, in the view of the majority in the Beuze Judgment, even if such denial took place, there is no automatic violation of the right to a fair trial, considering that the ECtHR would employ the test of overall fairness, giving the state the chance to redeem itself by proving that such a violation was remedied in the subsequent stages of criminal proceedings or that the criminal procedure was fair in view of other circumstances. Therefore, as a result of the more recent jurisprudence of the ECtHR, the suspect is deprived of the categorical right to access the defense attorney during the initial stages of criminal proceedings even though he had enjoyed that right under the Salduz doctrine. To put it simply, a systemic and mandatory restriction of the right to access to the defense attorney does not contradict fair trial rights according to the Beuze case.

To summarize, in bringing together both the Ibrahim Judgment and the Beuze Judgment, we may arrive at a devastating and shameful conclusion under which the suspect does not need to have the defense attorney during pre-trial proceedings, while his self-incriminating statements made in such context are admissible as evidence for reaching a conviction, whereby fair trial rights can be left aside if needed for the sake of convenience of police activities. 


\section{References}

- Ashworth, A. (2007) Security, Terrorism and the Value of Human Rights. In: Goold. B. \& Lazarus, L. (eds.) Security and Human Rights. Oxford: Hart Publishing, pp. 203-226.

- Burić, Z. (2018) Re-Assessing the Jurisprudence of the European Court of Human Rights on Police Interrogation-Case of Ibrahim and Others v. the United Kingdom. EU and comparative law issues and challenges series, 2(2), pp. 338-354. DOI: https://doi.org/10.25234/eclic/7116

- Celiksoy, E. (2018) Ibrahim and Others v. UK: Watering down the Salduz principles?. New Journal of European Criminal Law, 9(2), pp. 229-246. DOI: $10.1177 / 2032284418778149$

- Celiksoy, E. (2019) Overulling of 'the Salduz Doctrine' in Beuze v Belgium: The ECtHR's further retreat from the Salduz principles on the right to access to lawyer. New Journal of European Criminal Law, 10(4), pp. 1-21. DOI: $10.1177 / 2032284419879228$

- Giannoulopoulos, D. (2019) Improperly Obtained Evidence in Anglo-American and Continental Law. Oxford: Hart Publishing.

- Goss, R. (2014) Criminal Fair Trial Rights: Article 6 of the European Convention on Human Rights. London: Hart Publishing.

- Goss, R. (2017) Out of Many, One? Strasbourg's Ibrahim Decision on Article 6. The Modern Law Review, 80(6), pp. 1137-1150.

- Goss, R. (2019) The Undermining of Article 6 ECHR. In: Czech, P. et al. (eds.) European Yearbook on Human Rights 2019. Cambridge: Intersentia, pp. 295-312. DOI: https://doi.org/10.1017/9781780689562.014

- Ramos, V. C. (2016) The Rights of the Defence According to the ECtHR: An Illustration in the Light of ATV Luxembourg and the Right to Legal Assistance. New Journal of European Criminal Law, 7(4), pp. 397-417. DOI: $10.1177 / 203228441600700403$

- Sakowicz, A. (2021) Suspect's access to a lawyer at an early stage of criminal proceedings in view the case-law of the European Court of Human Rights. Revista Brasileira de Direito Processual Penal, 7(3), pp. 1979-2014. DOI: set./dez. 2021. https://doi.org/10.22197/rbdpp.v7i3.565.

- Sidhu, O. (2017) The Concept of Equality of Arms in Criminal Proceedings under Article 6 of the European Convention on Human Rights. Cambridge/ Antwerp/Portland: Intersentia.

- Soo, A. (2017) Divergence of European Union and Strasbourg Standards on Defence Rights in Criminal Proceedings? Ibrahim and the others v. the uk 
(13th of September 2), European Journal of Crime, Criminal Law and Criminal Justice, 25(4), pp. 327-346. DOI: 10.1163/15718174-02504002

- Soo, A. (2018) (Effective) Remedies for a Violation of the Right to Counsel during Criminal Proceedings in the European Union: An Empirical Study. Utrecht Law Review, 14(1), pp. 18-60. DOI: http://doi.org/10.18352/ulr.418

- Trechsel, S. (2005) Human Rights in Criminal Proceedings. New York: Oxford University Press.

\section{Legal Instruments}

- Convention for the Protection of Human Rights and Fundamental Freedoms, available at: https://www.echr.coe.int/documents/convention_eng.pdf, accessed: 30 October 2021.

Decisions of the European Court of Human Rights

- ECtHR, A.T. v. Luxembourg, no. 30460/13, 9 Judgment of April 2015 (A.T. v. Luxembourg).

- ECtHR, Aras v. Turkey (no. 2), no. 15065/07, Judgment of 18 November 2014 (Aras v. Turkey (no. 2)).

- ECtHR, Artico v. Italy, no. 6694/74, Judgment of 13 May 1980, Series A no. 37 (Artico v. Italy).

- ECtHR, Begu v. Romania, no. 20448/02, Judgment of 15 March 2011 (Begu v. Romania).

- ECtHR, Beuze v. Belgium, no. 71409/10, Judgment of 9 November 2018 [GC] (Beuze v. Belgium, [GC]).

- ECtHR, Borg v. Malta, no. 37537/13, Judgment of 12 January 2016 (Borg v. Malta).

- ECtHR, Brennan v. the United Kingdom, no. 39846/98, Judgment of 16 October 2001, ECHR 2001-X (Brennan v. the United Kingdom).

- ECtHR, Brusco v. France, no. 1466/07, Judgment of 14 October 2010 (Brusco v. France).

- ECtHR, Dayanan v. Turkey, no. 7377/03, Judgment of 13 October 2009 (Dayanan v. Turkey).

- ECtHR, Doyle v. Ireland, no. 51979/17, Judgment of 24 May 2019 (Doyle v. Ireland).

- ECtHR, Dvorski v. Croatia, no. 25703/11, Judgment of 20 October 2015 [GC] (Dvorski v. Croatia, [GC]).

- ECtHR, Hulki Güneş v. Turkey, no. 28490/95, Judgment of 19 June 2003, Reports of Judgments and Decisions 2003-VII (Hulki Güneş v. Turkey). 
- ECtHR, İbrahim Öztürk v. Turkey, no. 16500/04, Judgment of 17 February 2009 (İbrahim Öztürk v. Turkey).

- ECtHR, Ibrahim and Others v. the United Kingdom, nos. 50541/08, 50571/08, 50573/08 \& 40351/09, Judgment of 13 September 2016 [GC] (Ibrahim and Others v. the United Kingdom [GC])

- ECtHR, Imbrioscia v. Switzerland, no. 13972/88, Judgment of 24 November 1993, Series A no. 275 (Imbrioscia v. Switzerland).

- ECtHR, John Murray v. the United Kingdom, no. 18731/91, Judgment of 8 February 1996 [GC], Reports of Judgments and Decisions 1996-I (John Murray v. the United Kingdom, [GC]).

- ECtHR, Papon v. France, no. 54210/00, Judgment of 25 July 2002 (Papon v. France).

- ECtHR, Quaranta v. Switzerland, no. 12744/87, Judgment of 24 May 1991, Series A no. 205 (Quaranta v. Switzerland).

- ECtHR, Salduz v. Turkey, no. 36391/02, Judgment of 26 April 2007 (Salduz v. Turkey).

- ECtHR, Salduz v. Turkey, no. 36391/02, Judgment of 27 November 2008 [GC] (Salduz v. Turkey, [GC]).

- ECtHR, Simeonovi v. Bulgaria, no. 21980/04, Judgment of 12 May 2017 [GC] (Simeonovi v. Bulgaria).

- ECtHR, Teixeira de Castro v Portugal, no. 25829/94, Judgment of 9 June 1998, Reports of Judgments and Decisions 1998-IV (Teixeira de Castro $v$ Portugal).

- ECtHR, Zherdev v. Ukraine, no. 34015/07, Judgment of 27 April 2017 (Zherdev v. Ukraine). 